\title{
Impact of Noise in the Industry and Commercial areas in Ghana: Case Study of the Kumasi metropolis
}

\author{
1*Abankwa E.O., ${ }^{2}$ Agyei-Agyemang A., ${ }^{3}$ Tawiah P.O. \\ ${ }^{1}$ Department of Mechanical and Industrial Engineering, University for Development Studies, Tamale, Ghana \\ ${ }^{2,3}$ Department of Mechanical Engineering, KNUST, Kumasi, Ghana \\ Corresponding Author: Abankwa E.O
}

\begin{abstract}
To check the noise levels in the industry and commercial areas in Kumasi Metropolitan area, bus terminals and timber industries were selected and investigated. Measurements of daytime noise levels was carried out in three bus terminals and two timber industries, using DT-8852 Precision digital sound level meter. The three bus terminals were the Kwame Nkrumah University of Science and Technology (KNUST) Junction, Anloga Junction and Kejetia. The results showed that they had daytime noise levels of $78.8 \mathrm{dBA}, 72.1 \mathrm{dBA}$ and 78.3 $\mathrm{dBA}$ respectively. For the two timber industries, company A and B, their day time noise levels were $84.1 \mathrm{dBA}$ and $82.4 \mathrm{dBA}$. Comparing the results with the Ghana Environmental Protection Agency (EPA) standards, the three bus terminals had their day time noise levels exceeding the permissible levels by $8.8 \mathrm{dBA}, 2.1 \mathrm{dBA}$ and $8.3 \mathrm{dBA}$ respectively, while the timber industries had their day time noise levels exceeding the permissible levels by $14.1 \mathrm{dBA}$ and $12.4 \mathrm{dBA}$ respectively. The levels are alarming therefore it is recommended that the public be made aware of the adverse effects of noise pollution and necessary law enforcement steps taken to check it.
\end{abstract}

Keywords: Noise pollution, noise levels, measurement, permissible levels

Date of Submission: 13-07-2017

Date of acceptance: 15-07-2017

\section{INTRODUCTION}

Noise is generally defined as unpleasant sounds which disturb the human being physically and physiologically, as well as causes environmental pollution by destroying environmental properties [1]. Inphysics, soundis a vibrationthat propagates as a typically audible mechanical wave of pressure and displacement, through a Medium such as airorwater. Sound is the result of pressure changes in a medium (usually air), caused by vibration. The amplitude of these changes is stated in terms of sound level, and the rapidity with which these changes occur is the sound's frequency. Sound level is measured in decibels $(\mathrm{dB})$, and sound frequency is stated in terms of cycles per second, hertz (Hz.). Sound level is a logarithmic rather than a linear measure of the change in pressure with respect to a reference pressure level. A small increase in decibels can represent a large increase in sound energy. Technically, an increase of $20 \mathrm{~dB}$ represents a hundredfold increase of sound energy, and an increase of $30 \mathrm{~dB}$ represents a thousandfold increase of sound energy [2]. The human ear, perceives $1 \mathrm{~dB}$ increase as not noticeable, $3 \mathrm{~dB}$ increase as barely noticeable, $5 \mathrm{~dB}$ increase as clearly noticeable change, $10 \mathrm{~dB}$ increase as doubling of loudness and $20 \mathrm{~dB}$ increase as quadruple of loudness [3].
The general effect of noise has been a topicdebated among scientists for a number of years [4],[5], [6]. Regulations limiting noise exposure of industrial workers have been instituted in many places. For example, in the United States of America, the Occupational Noise Exposure Regulation states that industrial employers must limit noise exposure of their workersto $90 \mathrm{dBA}$ for a period of 8 hours [7],[8].

Exposure to continuous and intense noise levels higher than $85 \mathrm{dBA}$ may lead to hearing loss. Continuous hearing loss differs from person to person with the level, frequency and duration of the noise exposed [9].

Noise causes changes in hormones involved in the physiological process of fertility and in semen analysis parameters [10]. This points to the fact that, noise has harmful effects on fertility. In their study, Chamkori et al.[10]noticed that statistical studies showed that noise stress in the 119-decibel group significantly reduced the concentrations of the testosterone, prolactin, LH, and FSH hormones and of the thyroid hormones $\mathrm{T} 3, \mathrm{~T} 4$, and $\mathrm{TSH}$, and significantly increased the concentrations of the ACTH and cortisol hormones, compared to a control group; and moreover, semen analysis indicated major changes in semen parameters due to exposure to noise, especially under 119-decibel.

Noise stress can influence male sexual hormones and cause changes in reproductive glands 
and organs [11]. The prolonged exposure to a noise level of 100-decibel has permanent effects on testicular histology and morphology, and changes serum levels of testosterone, whose long-term changes can cause structural changes in testicles, stop maturation of germ cells, increase the number of dead and agglutinated sperms and, thus, can lead to infertility [12]. Industrial noise exceeding $80 \mathrm{~dB}$, could be a contributing factor in the development of arterial hypertension [13]. The audiometric test results of workers exposed to noise levels between $56.0 \mathrm{~dB}(\mathrm{~A})$ and $100.9 \mathrm{~dB}(\mathrm{~A})$ in a wheat processing factory, in which only $25.6 \%$ of all the readings was below the specified limit of $85 \mathrm{~dB}(\mathrm{~A})$, revealed that $33 \%$ of the examined workers had a defect in their left or right ear [14].

Road traffic noise can both directly and indirectly affect health condition of people [15]. The direct health effects found include hearing loss and cardiovascular effects, while the indirect health effects found, which involve moderating or mediating factors, include annoyance and sleep disturbance [16].

Road traffic noise in urban areas can lead to stress and sleep disturbances. It has been observed that both excess of stress hormones and reduction in sleep quality and duration may lead to a higher risk for type 2 diabetes [17]. In their study on the association between exposure to road traffic noise and incident diabetes, Sørensen et al.,[17], established that a 10-dB higher level of average road traffic noise at diagnosis and during the 5 years preceding diagnosis was associated with an increased risk of incident diabetes. They found a statistically significant positive association between long-term exposure to road traffic noise at the residence and the risk of incident diabetes, which suggests that reducing population exposure to road traffic noise may improve health.The analysis of a combined study of Cappuccio et al., using a sample of 100,000 participants and 3,586 incident cases indicated that both the quality and quantity of sleep consistently and significantly predicted the risk of type 2 diabetes [18]. This indicates that epidemiological studies also support a relationship between sleep disturbances and diabetes.

The exposure to traffic noise has been observed to be associated with cardiovascular disease [19],[20]. Noise acting as a stressor, according to the general stress model, can provoke a typical stress response, including hyperactivity of the sympathetic autonomic nervous system and activation of the hypothalamus-pituitary-adrenal axis, which can result in increased blood pressure, increased heart rate, and high levels of the glucocorticoid cortisol [16],[21]. In another study, the experimental reduction in the duration or quality of sleep in human volunteers was observed to have been associated with alterations in glucose regulation including a drop in glucose tolerance [22], increased morning levels of glucose, as well as a decrease in the levels of insulin [23].

Data show that exposure to traffic noise, not specifically at night, is associated with increased incidence of diabetes [17], hypertension [24], as well as increased incidence and mortality from coronary heart disease [25], [26]. In their study, Orban et al.,[27], concluded that long-term exposure to road traffic noise may increase the risk of depressive symptoms. Their study revealed that there was about 25-30\% more frequent high depressive symptoms in participants exposed to road traffic noise levels greater than $55 \mathrm{~dB}(\mathrm{~A})$ than in participants exposed to noise levels less than or equal to $55 \mathrm{~dB}(\mathrm{~A})$. Further analysis showed that, association remained stable after adjustment for various covariates, highlighting the robustness of their results when considering potential confounding factors [27].

From animal studies, there is evidence for associations between noise exposure and adverse reproductive outcomes; although few studies have been conducted in humans, there is some suggestive evidence of adverse associations with environmental noise from both occupational and epidemiological studies, especially for low birthweight. [28].

In a study in Ghana, more than half of the workers within the Tema Industrial Area, Tema, Ghana, who participated in a study: "The level of industrial noise and associated health effects on workers", were suffering from occupational noiseinduced hearing loss and reported difficulties to hear words clearly in normal conversations [29].

The Environmental Protection Agency (EPA), the leading public body for protecting and improving the environment in Ghana are to ensure thatair, land and water are looked after by everyone in the society, so that future generations inherit a cleaner and healthier world [30]. The EPAagency puts permissible ambient noise levels in residential areas at 55 decibels $(\mathrm{dB})$ during the day and $48 \mathrm{~dB}$ at night. Permissible noise levels around educational and health facilities is $55 \mathrm{~dB}$ during the day and 50 $\mathrm{dB}$ at night, while the noise level for areas with commercial or light industrial activities is registered as $60 \mathrm{~dB}$ and $55 \mathrm{~dB}$ during the day and night respectively. The new guidelines also permit $65 \mathrm{~dB}$ noise levels during the day and $60 \mathrm{~dB}$ during the night for light industrial areas and places of entertainment and public assembly such as churches and mosques. Predominantly commercial areas, according to the guidelines, are allowed $70 \mathrm{~dB}$ during the day and $65 \mathrm{~dB}$ at night, while the noise level for heavy industrial areas was pegged at $70 \mathrm{~dB}$ during the day and night. [31].

The recognition of noise as a serious hazard as opposed to nuisance is a recent development and 
the health effects of the hazardous noise exposure are now considered to be an increasingly important public health problem [32].

It has been observed that noise pollution is on the rise in the Ghanaian environment with the cities being the worst affected. Kumasi, the Capital city of Ashanti Region, is not an exception. Most business activities in Ashanti region take place in Kumasi and noise plays a major role in affecting business negatively.

Two weighting network namely the A and $\mathrm{C}$ network are used in measurement of sound. However, for environmental purposes, the measurement is made using an A-weighted scale (dBA) because this scale measures sound level in approximately the same way as the human ear [33].

The objective of this study is to investigate noise levels in the Kumasi metropolis by measuring noise levels at some identified areas in Kumasi to determine whether the noise generated in the industry and commercial areas in the Kumasi metropolis is beyond acceptable limits set by the EPA, Ghana, and make appropriate recommendations.

\section{MATERIALS AND METHODS}

Kumasi, the capital city of the Ashanti Region and the second biggest city in Ghana, with approximately 2.0 million inhabitants, has rising levels of noise pollution. Kumasi is situated about $250 \mathrm{~km}$ northwest of Accra and has a geographical location of $06^{\circ} 41^{\prime} \mathrm{N}$ latitude and $01^{\circ} 28^{\prime} \mathrm{W}$ longitude. Most business activities in the Ashanti Region take place in Kumasi and noise pollution will surely play a major role in affecting business negatively.

Measurement of noise levels was done in some industries and bus terminals. Two timber companies and three bus terminals were selected for this study. In this research, the measurement of noise level was done using a sound level meter which conforms to IEC 61672 standards. The Instrumentation for the measurement of noise levels in this study consisted of a DT-8852 Precision digital sound Level meter. It is to IEC 61672-1 Type 2, ANSI S1.4 Type 2 standard, with $1 / 2$ inch dielectric condenser microphone and 1/3-octave filter with a frequency range and measuring range of $31.5 \mathrm{~Hz}-$ $8 \mathrm{KHz}$ and $30 \mathrm{~dB}-130 \mathrm{~dB}$, respectively.

The instrument was calibrated before taking measurements. In the calibration procedure, the frequency weighting, time weighting and level range were switched to A-weighting, Fast and 50-100dB respectively. The microphone housing was inserted carefully into the $1 / 2$ inch insertion hole of the calibrator and the switch of the calibrator was turned on. The call potentiometer of the unit was adjusted to display $94.0 \mathrm{~dB}$. The noise level meter was designed for noise project, quality control, illness prevention \& cure and all kinds of environmental sounds measurements. It is applied to the sound measurement at factory, school, office, traffic access and household, among others.

Noise levels were measured for three working days for each company. The sound level meter was carefully mounted on a tripod at a height of 1.5 metres above the ground for all the two timber companies for consistency with the antenna facing the sound source. The instrument was calibrated to A-weighting for general noise level. The measurement process was carried out for two timber companies at the Kaase industrial area. Measurements were recorded for a period of 1 hour at 1 secondintervals, per sampling location. The procedure was carried out for the morning, 8:35-9:35 am and afternoon, 11:00 am-12:00 noon. Three appropriate locations were selected for the noise level measurement at the companies. The digital sound level meter was placed at a distance of 3 meters at from the sound source.

Noise levels were also measured at three (3) bus terminals namely KNUST bus terminal, Anloga bus terminal and the Kejetia bus terminal. The sound level meter was positioned at a height of 1.5 metres above the ground. The instrument was held at a distance of 3 metres from the noise source. This measurement process was carried out for three locations at each Bus Terminal at two different periods of time of the day: 8.35-9.35 am and 11.0012.00 noon for nine working days, altogether.

Measured noise level was used in the calculation of the day time noise level and night time noise level. The equations used for the calculationsare Equation 1 for daytime and Equation 2 for night time noise levels:

$$
L_{D}=10 \log \left[\frac{1}{2}\left[\left(10^{L_{A e q M} / 10}\right)+\left(10^{L_{A e q A} / 10}\right)\right]\right]
$$

$$
L_{N}=10 \log \left[\frac{1}{2}\left[\left(10^{L_{A e q E} / 10}\right)+\left(10^{L_{A e q N} / 10}\right)\right]\right]
$$

\section{Where}

$L_{\text {Aeq }}=$ The A-weighted equivalent sound pressure level

$L_{\text {Aeq } M}=$ The equivalent sound pressure for the morning measurement

$L_{A e q A}=$ The equivalent sound pressure level for the afternoon measurement

$L_{\text {AeqE }}=$ The equivalent sound pressure level for the evening measurement

$L_{\text {AeqN }}=$ The equivalent sound pressure level for the night measurement

$L_{D}=$ Day time noise level

$L_{N}=$ Night time noise level 
Tables 1, 2 and 3 show sample raw data that weremeasured, recorded and used to compute for the equivalent sound levels for KNUST Bus Terminal, Anloga Bus Terminal and for Kejetia Bus Terminal respectively.

Table 1: Sample data from KNUST Bus Terminal

\begin{tabular}{lll}
\hline & $\begin{array}{c}\text { KNUST Bus } \\
\text { Terminal }\end{array}$ & (dBA) \\
\hline $8: 35: 00$, & $8: 35: 12$, & $8: 35: 24$, \\
80.40 & 85.00 & 82.70 \\
$8: 35: 01$, & $8: 35: 13$, & $8: 35: 25$, \\
73.60 & 77.70 & 88.80 \\
$8: 35: 02$, & $8: 35: 14$, & $8: 35: 26$, \\
90.90 & 88.20 & 75.70 \\
$8: 35: 03$, & $8: 35: 15$, & $8: 35: 27$, \\
73.20 & 90.00 & 89.40 \\
$8: 35: 04$, & $8: 35: 16$, & $8: 35: 28$, \\
82.30 & 74.70 & 75.70 \\
$8: 35: 05$, & $8: 35: 17$, & $8: 35: 29$, \\
\hline
\end{tabular}

Table 2: Sample data from Anloga Bus Terminal

\begin{tabular}{|l|l|l|}
\hline & $\begin{array}{c}\text { Anloga Bus } \\
\text { Terminal }\end{array}$ & (dBA) \\
\hline $8: 35: 33$, & $8: 35: 44$, & $8: 35: 55,61.50$ \\
69.60 & 65.50 & $8: 35: 56,63.40$ \\
$8: 35: 34$, & $8: 35: 45$, & $8: 35: 57,66.90$ \\
65.20 & 71.60 & $8: 35: 58,64.00$ \\
$8: 35: 35$, & $8: 35: 46$, & $8: 35: 59,65.40$ \\
71.60 & 64.70 & $8: 36: 00,67.10$ \\
$8: 35: 36$, & $8: 35: 47$, & $8: 36: 01,72.80$ \\
70.40 & 64.70 & $8: 36: 02,75.70$ \\
$8: 35: 37$, & $8: 35: 48$, & $8: 36: 03,67.90$ \\
63.60 & 64.00 & $8: 36: 04,69.80$ \\
$8: 35: 38$, & $8: 35: 49$, & $8: 36: 05,75.30$ \\
64.40 & 64.70 & \\
$8: 35: 39$, & $8: 35: 50$, & \\
66.00 & 63.20 & \\
$8: 35: 40$, & $8: 35: 51$, & \\
66.60 & 62.40 & \\
$8: 35: 41$, & $8: 35: 52$, & \\
66.90 & 63.40 & \\
$8: 35: 42$, & $8: 35: 53$, & \\
67.80 & 68.40 & \\
$8: 35: 43$, & $8: 35: 54$, & \\
66.30 & 61.20 & \\
\hline & & \\
\hline
\end{tabular}

\begin{tabular}{lll}
\hline 76.50 & 82.70 & 89.00 \\
$8: 35: 06$, & $8: 35: 18$, & $8: 35: 30$, \\
76.50 & 74.90 & 83.00 \\
$8: 35: 07$, & $8: 35: 19$, & $8: 35: 31$, \\
87.00 & 89.40 & 85.50 \\
$8: 35: 08$, & $8: 35: 20$, & $8: 35: 32$, \\
91.30 & 86.40 & 91.50 \\
$8: 35: 09$, & $8: 35: 21$, & $8: 35: 33$, \\
85.90 & 89.00 & 72.60 \\
$8: 35: 10$, & $8: 35: 22$, & $8: 35: 34$, \\
84.30 & 84.90 & 78.60 \\
$8: 35: 11$, & $8: 35: 23$, & $8: 35: 35$, \\
89.70 & 79.60 & 95.60 \\
& & \\
\hline
\end{tabular}

Table 3: Sample data from Kejetia Bus Terminal

\begin{tabular}{|c|c|c|}
\hline & $\begin{array}{c}\text { Kejetia Bus } \\
\text { Terminal }\end{array}$ & (dBA) \\
\hline $\begin{array}{l}8: 35: 00,79.60 \\
8: 35: 01,88.40 \\
8: 35: 02,76.30 \\
8: 35: 03,80.40 \\
8: 35: 04,74.90 \\
8: 35: 05,81.20 \\
8: 35: 06,75.70 \\
8: 35: 07,79.60 \\
8: 35: 08,78.80 \\
8: 35: 09,71.00 \\
8: 35: 10,71.80 \\
8: 35: 11,76.90\end{array}$ & $\begin{array}{l}8: 35: 12, \\
77.10 \\
8: 35: 13, \\
78.30 \\
8: 35: 14, \\
75.90 \\
8: 35: 15 \\
76.90 \\
8: 35: 16, \\
74.50 \\
8: 35: 17, \\
76.70 \\
8: 35: 18 \\
85.10 \\
8: 35: 19 \\
75.90 \\
8: 35: 20 \\
74.50 \\
8: 35: 21 \\
74.50 \\
8: 35: 22 \\
75.90 \\
8: 35: 23, \\
76.90\end{array}$ & $\begin{array}{l}8: 35: 24, \\
75.70 \\
8: 35: 25, \\
74.90 \\
8: 35: 26, \\
81.70 \\
8: 35: 27, \\
83.70 \\
8: 35: 28, \\
89.80 \\
8: 35: 29, \\
73.00 \\
8: 35: 30, \\
86.20 \\
8: 35: 31, \\
81.60 \\
8: 35: 32, \\
74.90 \\
8: 35: 33, \\
81.60 \\
8: 35: 34, \\
79.30 \\
8: 35: 35, \\
81.60\end{array}$ \\
\hline
\end{tabular}

Figs. 1,2 and 3 show the graphs of the sound levels measured during a period of one hour for the three respective bus terminals.

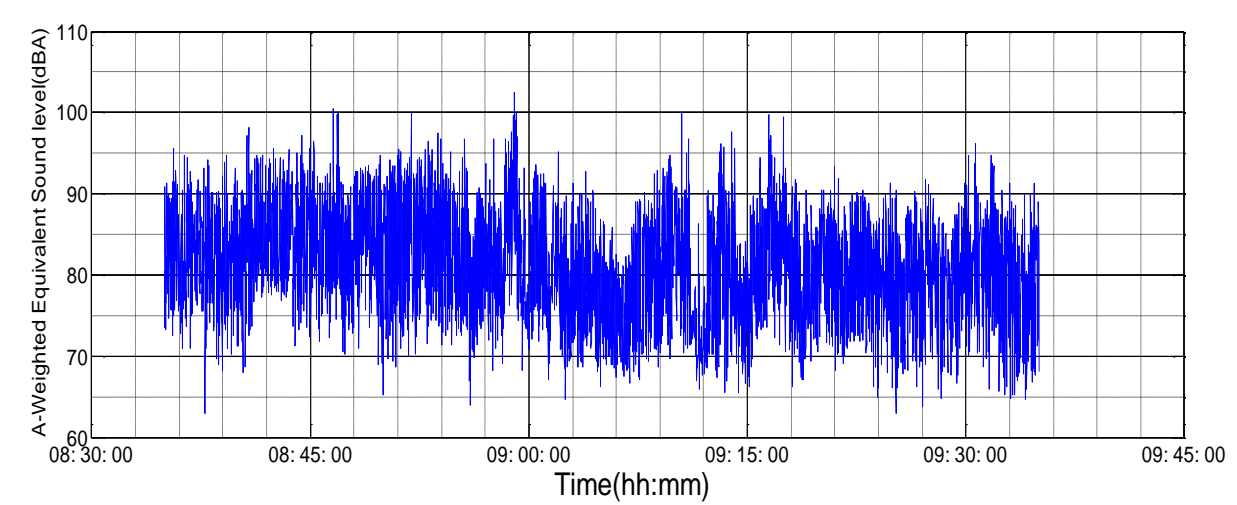

Figure 1: Graph of measured sound levels at KNUST Bus Terminal in the morning (Day 1) 


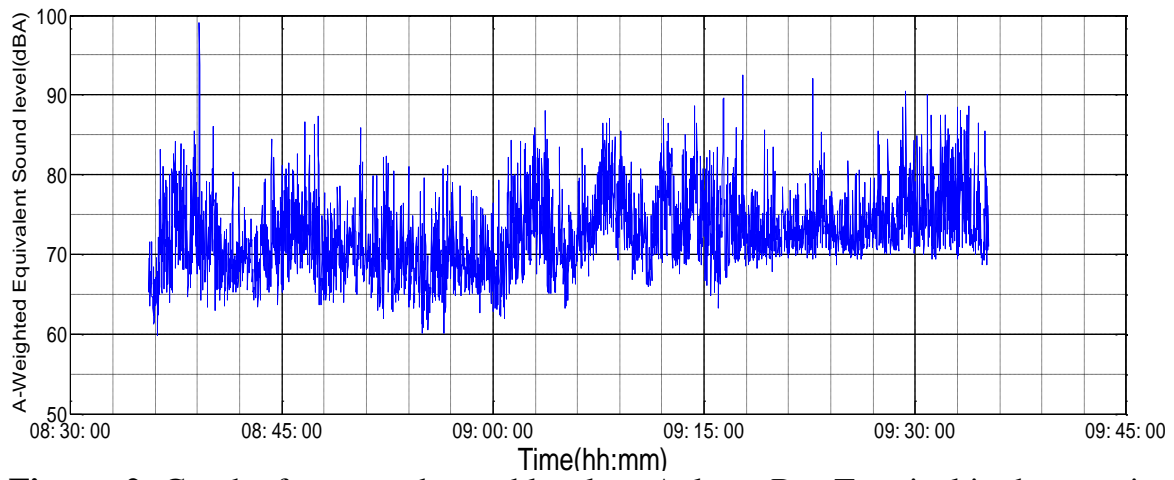

Figure 2: Graph of measured sound levels at Anloga Bus Terminal in the morning (Day 1)

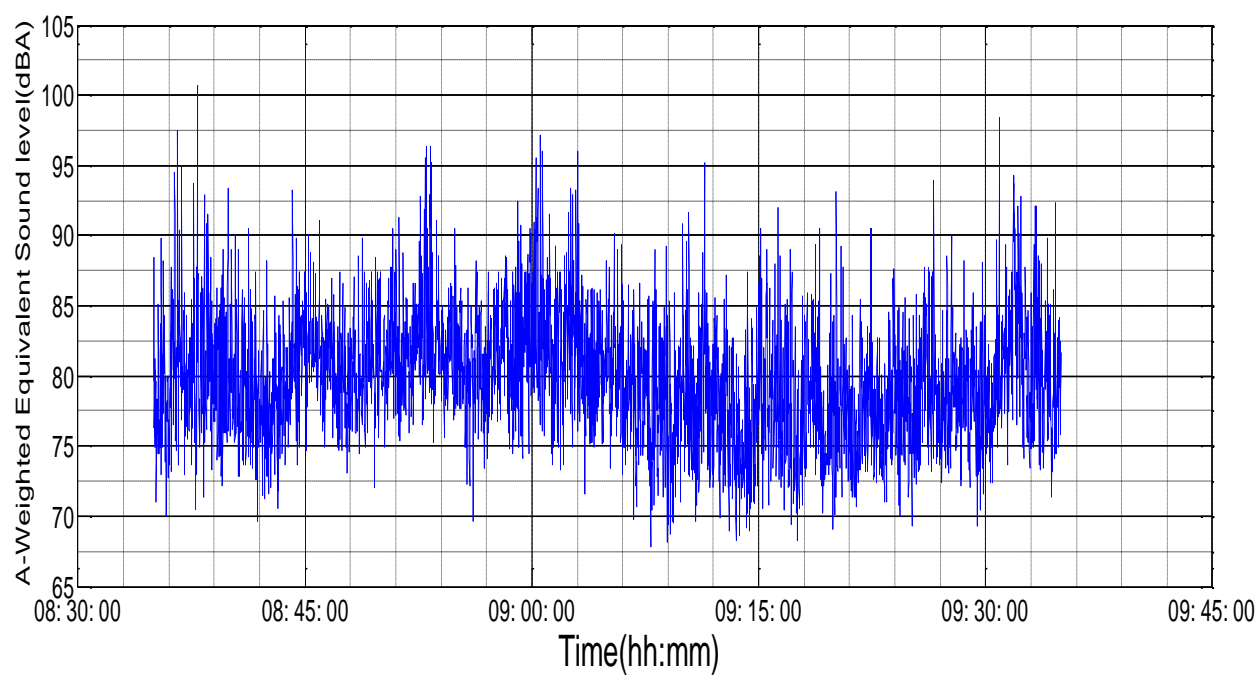

Figure 3: Graph of measured sound levels at Kejetia Bus Terminal in the morning (Day1)

The results of sound level measurements are presented in Tables 4, 5 and 6.Tables 4, 5, and 6 show that there is variation in noise level for each period of the day for the bus terminals. InTable 4, the results of the equivalent sound levels for the morning and afternoon sessions for Kwame Nkrumah University of Science and Technology (KNUST) Bus Terminal are presented for each day. Day two recorded the highest sound level for the morning and afternoon session of $82.7 \mathrm{dBA}$ and $82.5 \mathrm{dBA}$ respectively

Table 4: Equivalent sound levels for the morning and afternoon session for KNUST Bus Terminal

\begin{tabular}{llll}
\hline & Day 1 & Day2 & Day 3 \\
\hline Morning & $81.4 \mathrm{dBA}$ & 82.7 & 75.6 \\
& & $\mathrm{dBA}$ & $\mathrm{dBA}$ \\
Afternoon & \multirow{2}{*}{$73.7 \mathrm{dBA}$} & 82.5 & 75.7 \\
& & $\mathrm{dBA}$ & $\mathrm{dBA}$ \\
\hline
\end{tabular}

Table 5 presents the results of the equivalent sound levels for the morning and afternoon sessions for Anloga Bus Terminal for each day. Day three recorded the highest sound levels of $72.7 \mathrm{dBA}$ and
$72.8 \mathrm{dBA}$ for the morning and afternoon sessions respectively.

Table 5: Equivalent sound levels for the morning and afternoon session for Anloga Bus Terminal

\begin{tabular}{llll}
\hline & Day1 & Day2 & Day3 \\
\hline Morning & $72.6 \mathrm{dBA}$ & 72.3 & 72.7 \\
& & $\mathrm{dBA}$ & $\mathrm{dBA}$ \\
Afternoon & $70.1 \mathrm{dBA}$ & 71.9 & 72.8 \\
& & $\mathrm{dBA}$ & $\mathrm{dBA}$ \\
\hline
\end{tabular}

Table 6 presents the results of the equivalent sound levels for the morning and afternoon sessions for Kejetia Bus Terminal. Day two recorded the highest sound level of $81.3 \mathrm{dBA}$ and $80.5 \mathrm{dBA}$ respectively.

Table 6: Equivalent sound levels for the morning and afternoon session for Kejetia Bus Terminal

\begin{tabular}{llll}
\hline & Day 1 & Day 2 & Day 3 \\
\hline Morning & $79.8 \mathrm{dBA}$ & 81.3 & $74 \mathrm{dBA}$ \\
& & $\mathrm{dBA}$ & \\
Afternoon & $79.8 \mathrm{dBA}$ & 80.5 & 74.3 \\
& & $\mathrm{dBA}$ & $\mathrm{dBA}$ \\
\hline
\end{tabular}


Table 7 gives the average noise level for the morning and afternoon sessions for the three Bus Terminals. It also shows daytime noise level which was calculated using the average morning and afternoon noise values and Equation 1.

Table 7: Daytime noise level for the three Bus Terminals

\begin{tabular}{llcc}
\hline & $\begin{array}{c}\text { KNUST } \\
\text { Bus } \\
\text { Terminal }\end{array}$ & $\begin{array}{c}\text { Anloga } \\
\text { Bus } \\
\text { Terminal }\end{array}$ & $\begin{array}{c}\text { Kejetia } \\
\text { Bus } \\
\text { Terminal }\end{array}$ \\
\hline Morning & $79.9 \mathrm{dBA}$ & $72.5 \mathrm{dBA}$ & $78.4 \mathrm{dBA}$ \\
Afternoon & $77.3 \mathrm{dBA}$ & $71.6 \mathrm{dBA}$ & $78.2 \mathrm{dBA}$ \\
$\begin{array}{l}\text { Daytime } \\
\text { noise level }\end{array}$ & $78.8 \mathrm{dBA}$ & $72.1 \mathrm{dBA}$ & $78.3 \mathrm{dBA}$ \\
\hline
\end{tabular}

The KNUST Bus Terminal recorded the highest daytime noise level of $78.8 \mathrm{dBA}$. This high value is attributed to the fact that there were a lot of activities at the terminal during the daytime. The volume of vehicles plying the network of roads at this station is very high coupled with business activities on daily bases. Major sources of noise was from traffic noise, vehicle hooting, rolling tyres, human conversation, musical instruments, radios from vehicles as well as that of preaching using loud speakers. This attests to the finding of Essandoh and Armah (2011) that most environmental noise results from road traffic and commercial activities. The next to the KNUST was the Kejetia Bus Terminal, which recorded 78.3 dBA.The difference was quite small. There were a lot of activities during the day time and the volume of vehicles plying the roads connecting this station was high. Anloga Bus Terminal recorded the lowest daytime noise level of $72.1 \mathrm{dBA}$. This results from the fact that business and commercial activities at the station was minimal, relative to the other two terminals. Major sources of noise were traffic noise, vehicle hooting, rolling tires, human conversation and radios from vehicles.

The study revealed that the bus terminals were exposed to noise levels exceeding the maximum allowable limit of $70 \mathrm{dBA}$ for predominantly commercial areas. From Table 8, KNUST Bus terminal exceeded the allowable limit set by EPA by $8.8 \mathrm{dBA}$, Anloga Bus terminal exceeded the allowable limit by $2.1 \mathrm{dBA}$, and Kejetia Bus terminal exceeded the allowable limit by $8.3 \mathrm{dBA}$.

Table 8: Excess $\mathrm{dB}$ at the Bus terminals

\begin{tabular}{clll}
\hline & $\begin{array}{l}\text { Day time } \\
\text { noise } \\
\text { level }\end{array}$ & $\begin{array}{l}\text { EPA } \\
\text { Noise } \\
\text { level limit }\end{array}$ & Excess \\
\hline $\begin{array}{c}\text { KNUST } \\
\text { Bus }\end{array}$ & $\begin{array}{l}78.8 \\
\mathrm{dBA}\end{array}$ & $70 \mathrm{dBA}$ & $8.8 \mathrm{dBA}$ \\
$\begin{array}{c}\text { Terminal } \\
\text { Anloga } \\
\text { Bus }\end{array}$ & $\begin{array}{l}72.1 \\
\mathrm{dBA}\end{array}$ & $70 \mathrm{dBA}$ & $2.1 \mathrm{dBA}$ \\
\hline
\end{tabular}

\begin{tabular}{cccc} 
Terminal & & & \\
Kejetia & 78.3 & $70 \mathrm{dBA}$ & $8.3 \mathrm{dBA}$ \\
Bus & $\mathrm{dBA}$ & & \\
Terminal & & & \\
\hline
\end{tabular}

For the industrial area, Tables 9 and 10 are sample raw data from Company $\mathrm{A}$ and $\mathrm{B}$.

Table 9: Sample data from Company A

\begin{tabular}{lll}
\hline & Company A & (dBA) \\
\hline $8: 35: 00$, & $8: 35: 12,87.40$ & $8: 35: 24,90.40$ \\
87.10 & $8: 35: 13,91.30$ & $8: 35: 25,89.70$ \\
$8: 35: 01$, & $8: 35: 14,89.40$ & $8: 35: 26,89.30$ \\
88.20 & $8: 35: 15,87.00$ & $8: 35: 27,90.40$ \\
$8: 35: 02$, & $8: 35: 16,85.90$ & $8: 35: 28,89.80$ \\
86.80 & $8: 35: 17,87.00$ & $8: 35: 29,89.70$ \\
$8: 35: 03$, & $8: 35: 18,87.80$ & $8: 35: 30,89.40$ \\
87.00 & $8: 35: 19,91.20$ & $8: 35: 31,90.10$ \\
$8: 35: 04$, & $8: 35: 20,89.60$ & $8: 35: 32,88.80$ \\
87.40 & $8: 35: 21,89.80$ & $8: 35: 33,89.00$ \\
$8: 35: 05$, & $8: 35: 22,88.90$ & $8: 35: 34,88.80$ \\
87.90 & $8: 35: 23,88.80$ & $8: 35: 35,89.60$ \\
$8: 35: 06$, & & \\
87.40 & & \\
$8: 35: 07$, & & \\
87.30 & & \\
$8: 35: 08$, & & \\
88.00 & & \\
$8: 35: 09$, & & \\
87.90 & & \\
$8: 35: 10$, & & \\
86.80 & & \\
$8: 35: 11$, & & \\
88.40 & & \\
\hline
\end{tabular}

Table 10: Sample data from Company B

\begin{tabular}{lll}
\hline & Company B & $($ dBA $)$ \\
\hline $8: 35: 00$, & $8: 35: 12,82.20$ & $8: 35: 24$, \\
82.50 & $8: 35: 13,82.10$ & 81.10 \\
$8: 35: 01$, & $8: 35: 14,83.90$ & $8: 35: 25$, \\
81.00 & $8: 35: 15,84.30$ & 82.70 \\
$8: 35: 02$, & $8: 35: 16,81.60$ & $8: 35: 26$, \\
83.90 & $8: 35: 17,84.10$ & 81.90 \\
$8: 35: 03$, & $8: 35: 18,87.20$ & $8: 35: 27$, \\
90.50 & $8: 35: 19,83.40$ & 82.30 \\
$8: 35: 04$, & $8: 35: 20,82.10$ & $8: 35: 28$, \\
88.50 & $8: 35: 21,82.10$ & 81.20 \\
$8: 35: 05$, & $8: 35: 22,80.80$ & $8: 35: 29$, \\
83.50 & $8: 35: 23,81.00$ & 81.60 \\
$8: 35: 06$, & & $8: 35: 30$, \\
83.90 & & 84.30 \\
$8: 35: 07$, & & $8: 35: 31$, \\
83.50 & & 81.60 \\
$8: 35: 08$, & & $8: 35: 32$, \\
84.60 & & 82.20 \\
\hline
\end{tabular}




\begin{tabular}{ll}
\hline $8: 35: 09$, & $8: 35: 33$, \\
82.70 & 82.60 \\
$8: 35: 10$, & $8: 35: 34$, \\
82.60 & 84.30 \\
$8: 35: 11$, & $8: 35: 35$, \\
82.00 & 84.80 \\
\end{tabular}

Figs. 4 and 5 show the graphs of the sound levels measured during a period of one hour for the respective industries.

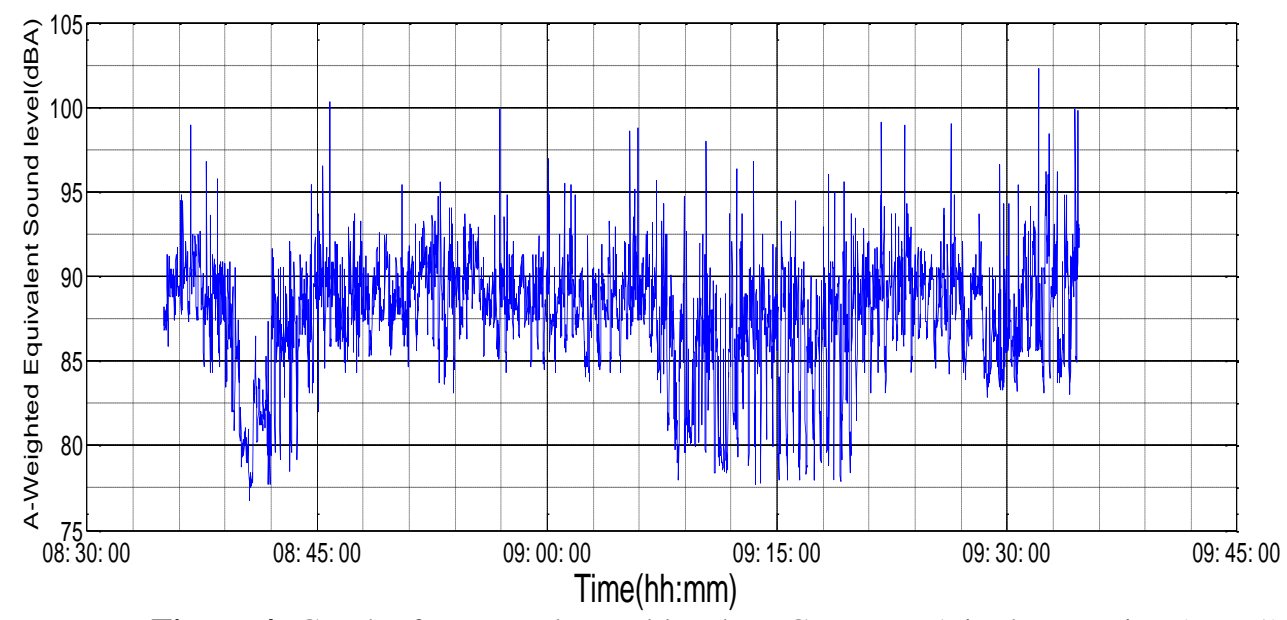

Figure 4: Graph of measured sound levels at Company A in the morning (Day 1)

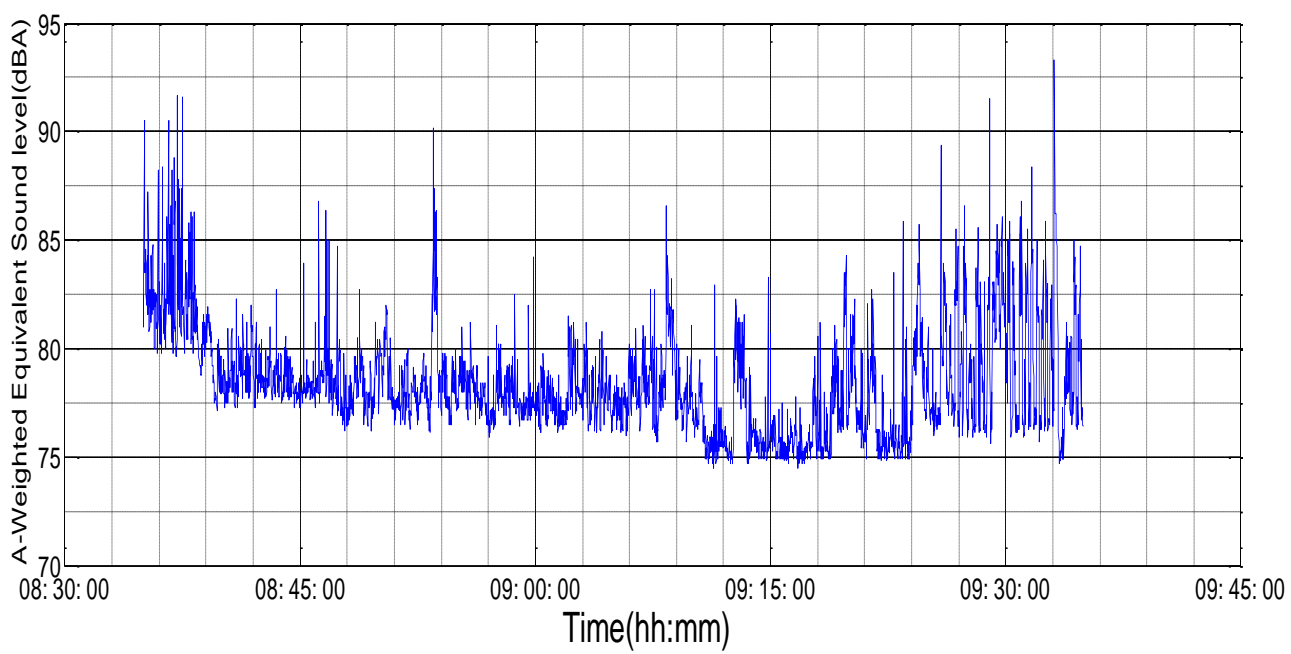

Figure 5: Graph of measured sound levels at Company B in the morning (Day1)

Tables 11, 12and 13 represent the variation in noise levels for the two timber companies studied. The results of the average equivalent sound levels for the morning and afternoon sessions for Company A and Company B respectively are presented in Table 11 and Table 12, for each day.

Table 11: Equivalent Sound Levels for the morning and afternoon sessions for Company $\mathbf{A}$

\begin{tabular}{llll}
\hline & Day 1 & Day2 & Day 3 \\
\hline Morning & $87.6 \mathrm{dBA}$ & 79.1 & 78.5 \\
& & $\mathrm{dBA}$ & $\mathrm{dBA}$ \\
Afternoon & $83.3 \mathrm{dBA}$ & 86.9 & 86.8 \\
\hline
\end{tabular}

\begin{tabular}{ll}
\hline $\mathrm{dBA}$ & $\mathrm{dBA}$ \\
\hline
\end{tabular}

Table 12: Equivalent Sound Levels for the morning and afternoon sessions for CompanyB

\begin{tabular}{llll}
\hline & Day 1 & Day2 & Day 3 \\
\hline Morning & $78.4 \mathrm{dBA}$ & 84.1 & 81.2 \\
& & $\mathrm{dBA}$ & $\mathrm{dBA}$ \\
Afternoon & $85.4 \mathrm{dBA}$ & 77.8 & 86.6 \\
& & $\mathrm{dBA}$ & $\mathrm{dBA}$ \\
\hline
\end{tabular}

Table 13gives the daytime noise levels for the two companies which were determined by using the average sound levels for the morning and afternoon sessions and Equation 1. 
Table 13: Day time noise level for Companies A and B.

\begin{tabular}{lll}
\hline & Company A & Company B \\
\hline Morning & $81.733 \mathrm{dBA}$ & $81.233 \mathrm{dBA}$ \\
Afternoon & $85.667 \mathrm{dBA}$ & $83.267 \mathrm{dBA}$ \\
Daytime noise level & $84.1 \mathrm{dBA}$ & $82.4 \mathrm{dBA}$ \\
EPA noise level & $70 \mathrm{dBA}$ & $70 \mathrm{dBA}$ \\
limit & & \\
Excess & $14.1 \mathrm{dBA}$ & $12.4 \mathrm{dBA}$
\end{tabular}

Company A recorded the highest daytime noise level of $84.1 \mathrm{dBA}$, while Company B recorded $82.4 \mathrm{dBA}$. Company A recorded the highest as a result of the fact that their working place was an open one so the noise did not emanate only from the machines in the working environment but also from outside the working environment, compared to Company B where the working environment was inside a building. The Noise sources were mainly machines like the band saw, cross cut saw, chain saw, edger saw, moulding machines and planning machines. The results show that the noise level from the industries were above the EPA-Ghana recommended level of $70 \mathrm{dBA}$ for predominantly heavy industrial areas.

\section{CONCLUSION}

The two timber industries, Company A and Company B recorded day time noise levels of 84.1 $\mathrm{dBA}$ and $82.4 \mathrm{dBA}$ respectively, exceeding the maximum allowable limits of $70 \mathrm{dbA}$ for predominantly heavy industrial areas set by the EPAGhana by $14.1 \mathrm{dBA}, 12.4 \mathrm{dBA}$ respectively.

The three bus terminals at KNUST Junction, Anloga Junction and Kejetia had day time noise levels of $78.8 \mathrm{dBA}, 72.1 \mathrm{dBA}$ and $78.3 \mathrm{dBA}$ respectively, exceeding the maximum allowable limit of $70 \mathrm{dBA}$ for predominantly commercial areas by $8.8 \mathrm{dBA}, 2.1 \mathrm{dBA}$ and $8.3 \mathrm{dBA}$ respectively.

The excess decibels at the Companies were between $10 \mathrm{dBA}$ and $20 \mathrm{dBA}$. Which means the change in decibel levels is between double loudness and quadruple loudness. The excess decibels at the bus terminals were less than $10 \mathrm{dBA}$, implying that the change in decibel levels werejust clearly noticeable. The noise levels at the areas arerather high and could pose a health risk to the people. Inthe industry, it will increase the risk of accidents because workers may not be able to hear and communicate effectively. On the other hand, long term exposure to road traffic noise, as experienced at the bus terminals, could increase the risk of depressive symptoms in people and affect their health and wellbeing. Considering noise levels at these areas, it could affect the cardiovascular systems resulting in an increase in blood pressure and also leading to possible hearing loss and other ill health.An urgent step should therefore be taken to reduce noise levels in these areas and also to enforce the use of ear protectors in the industry.

\section{REFERENCES}

[1] Melnick, W. Hearing loss from noise exposure. In C.M. Harris (Ed.), Handbook of Noise Control (2nd ed.). (New York: McGraw-Hill Book Company, 1979) Chapter 9,

[2] Suter, A. Noise and Its Effects, Administrative Conference of the United States, November, 1991.

[3] Claridge, S.. www.hearingaidknow.com. 4 June, 2013. Accessed November 22, 2013. http://www.hearingaidknow.com/.

[4] Jansen G. Effects of noise on human beings. VGB(Ger-man) 72 (1), 1992, 60.

[5] Johnson D. Field studies: Industrial Exposure. Journal of the Acoustical Society of America 90 (1), 1991, 170.

[6] Alton B., and Ernest J. Relationship between loss and noise exposure levels in a large industrial population: a re-view of an overlooked study. Journal of the Acoustical Society of America 88 (S1), 1990,S73 (A).

[7] United States Environmental Protection Agency (USEPA). Public health and welfare criteria for noise. United States Environmental Protection Agency, Washington (DC), July, 1973.

[8] Eleftheriou, P. C. Industrial noise and its effects on human hearing, Applied Acoustics, USEPA (United States Environmental Protection Agency). Information on levels of environmental noise requisite to protect public health and welfare with adequate margin of safety, (EPA/ONAC Rep. No. 550/9-74-004); 1974.63, 35, 2002).

[9] United States Environmental Protection Agency (USEPA). Public health and welfare criteria for noise. United States Environmental Protection Agency, Washington (DC), July, 1974.

[10] Chamkori Alireza, Shariati Mehrdad, Moshtaghi Darab, Farzadinia Parviz, Effect of Noise Pollution on the Hormonal and Semen Analysis Parameters in Industrial Workers of Bushehr, Iran; Crescent Journal of Medical and Biological Sciences, 3 (2), 2016, 45-50

[11] Swami C. G., Ramanathan R., Charan Jeganath A. noise exposure affect testicular histology and on male steroidogenic hormone. Malaysian Journal of Medical Sciences, 14 (2), 2007, 28-35.

[12] Ogale SB. Noise overload. Health Nutrients, 1999, 85- 89. 
[13] Sangeeta Singhal, Berendra Yadav, S.F. Hashmi, Md. Muzammil, Effects of workplace noise on blood pressure and heart rate, Biomedical Research, 20 (2), 2009, 122-126

[14] Ibrahim, I. B., Aremu, A. S., Ajao1 K. R., and Ojelabi A. T.Evaluation of Noise Pollution and Effects on Workers during Wheat Processing Journal of Applied Sciences and Environmental Management, 18 (4), 2014, $599-601$

[15] Babisch W. Noise and health. Environmental Health Perspectives, 113, 2005,A14-5.

[16] Ising H and Kruppa B. Health effects caused by noise: Evidence in the literature from the past 25 years. Noise Health, 6, 2004, 5-13.

[17] Sorensen M., Andersen Z.J., Nordsborg R.B., Becker T., Tjonneland A., Overvad K., et al. Long-term exposure to road traffic noise and incident diabetes: a cohort study, Environmental Health Perspectives, 121 (2), 2013, 217-222

[18] Cappuccio FP, D’Elia L, Strazzullo P, Miller MA. Quantity and quality of sleep and incidence of type 2 diabetes: a systematic review and meta-analysis. Diabetes Care, 33,2010, 414-420

[19] Babisch W. Transportation noise and cardiovascular risk: updated review and synthesis of epidemiological studies indicate that the evidence has increased. Noise Health, 8,2006, 1-29.

[20] Sørensen M, Hvidberg M, Andersen ZJ, Nordsborg R.B., Lillelund K.G., Jakobsen J., et al. Road traffic noise and stroke: a prospective cohort study. European Heart Journal, 32(6), 2011,737-744.

[21] Lusk SL, Gillespie B, Hagerty BM, Ziemba RA. Acute effects of noise on blood pressure and heart rate. Archives of Environmental Health, 59, 2004, 392-399.

[22] Spiegel K, Leproult R, Van CE. Impact of sleep debt on metabolic and endocrine function. Lancet, 354, 1999, 1435-1439.

[23] Spiegel K, Knutson K, Leproult R, Tasali E, Van CE. Sleep loss: a novel risk factor for insulin resistance and type 2 diabetes. Journal of Applied Physiology, 99, 2005, 2008-2019.

[24] ]Babisch W., Kamp I. Exposure-response relationship of the association between aircraft noise and the risk of hypertension; Noise Health, 11 (44), 2009, 161-168

[25] Huss A., Spoerri A., Egger M., Roosli M.

Aircraft noise, air pollution, and mortality from myocardial infarction, Epidemiology, 21 (6), 2010,829-836

[26] Babisch W.Updated exposure-response relationship between road traffic noise and coronary heart diseases: a meta-analysis, Noise Health, 16 (68), 2014, 1-9

[27] Orban, E.; , McDonald, K.; Sutcliffe, R.; Hoffmann, B.; Fuks, K. B.; Dragano, N. 4Viehmann, A.; Erbel, R.; Jöckel, K-H.; Pundt, N.; and Moebus, S.; Residential Road Traffic Noise and High Depressive Symptoms after Five Years of Follow-up: Results from the Heinz Nixdorf Recall Study; Environmental Health Perspectives, 124 (5), 2016,578-585

[28] Gordana Ristovska, Helga Elvira Laszlo and Anna L. Hansell; Reproductive Outcomes Associated with Noise Exposure - A Systematic Review of the Literature International Journal of Environmental Research and Public Health, 11(8), 2014, 7931-7952

[29] Omari, S., De-Veer, A., \& Amfo-Otu, R. The Silent Killer: An Assessment ofLevel of Industrial Noise and Associated Health Effects on Workers. International Journal of Basic and Applied Sciences, 2 (2), 2013, 165-169.

[30] Environmental Protection Agency (EPA), EPA Act 490, 1994, Guiding Principles, http://www.epa.gov.gh.

[31] Odoi-Larbi, S, EPA sets guidelines for noise-making. The Chronicle, $16^{\text {th }}$ May, 2012.The Chronicle, (http://thechronicle.com.gh/?p=44464) (Accessed 2013 April 12).

[32] World Health Organization, Occupation and Environmental Health, 2001, http://www.who.int/occupational_health/en/ (accessed 2013 May 19).

[33] Alam J. B., Alam M. J. B., Rahman M. M., Dikshit A. K., Khan S. K., Study on traffic noise level of Sylhet by multiple regression analysis associated with health hazards, Iranian Journal of Environmental Health Science \& Engineering 3 (2), 2006, 71-78.

[34] Olayinka O. S. and Abdullahi S. A., A statistical analysis of the day-time and night-time noise levels in Ilorin Metropolis, Nigeria, Trends in Applied Sciences Research, 3(3), 2008, 253-266.

Abankwa E.O. "Impact of Noise in the Industry and Commercial areas in Ghana: Case Study of the Kumasi metropolis." International Journal of Engineering Research and Applications (IJERA) 7.7 (2017): 11-19. 